\title{
A fast method for the determination of lead in honey samples using stabilizer-free silver nanoparticles
}

\author{
Dayana Borges Bittar, Tiago Augusto Catelani, Leonardo Pezza, Helena Redigolo Pezza* \\ Institute of Chemistry, Sao Paulo State University (UNESP), Rua Prof. Francisco Degni 55, P.O. Box 355, 14800-900 Araraquara, Sao Paulo, Brazil
}

\section{A R T I C L E I N F O}

\section{Article history:}

Received 16 May 2017

Received in revised form 7 August 2017

Accepted 9 August 2017

Available online 12 August 2017

\section{Keywords:}

Silver nanoparticles

Lead

Contamination

Honey

\begin{abstract}
A B S T R A C T
A sensitive, rapid and robust method based on the use of stabilizer-free silver nanoparticles was developed for lead detection in honey. Silver nanoparticles were synthesized without the presence of any stabilizers using silver nitrate and sodium borohydride as precursors where the latter was applied as reducing agent. The optimization of the experimental variables $\left(\mathrm{AgNO}_{3}\right.$ and $\left.\mathrm{NaBH}_{4}\right)$ for the formation of the nanoparticles was carried out using varying volumes of these solutions. Spectrophotometric measurements at $393 \mathrm{~nm}$ showed a linear working range between 0.0500 and $0.167 \mathrm{mg} \mathrm{L}^{-1}$ lead $(R=0.994)$, with limits of detection (LOD) and quantification (LOQ) of 0.0135 and $0.0451 \mathrm{mg} \mathrm{L}^{-1}$, respectively. The proposed method proved to be a significantly sensitive mechanism for lead detection in honey samples.
\end{abstract}

(c) 2017 Elsevier B.V. All rights reserved.

\section{Introduction}

Honey is a natural product known to be endowed with nutritional properties and valuable therapeutic applications [1]. It is used as a means of nourishment for feeding thousands of people, from childhood to adulthood. As a result of its ample consumption, the control of the chemical and microbiological quality of honey is deemed to be hugely relevant. It is a natural food produced by the Apis mellifera bees, being one of the most complex products produced in nature, and contains a complex mixture of carbohydrates, mainly glucose and fructose, enzymes, amino acids, organic acids, aromatic substances, vitamins, pigments, wax and pollen, which together contribute towards the composition of its color, odor and taste [2,3]. Its composition largely depends on the floral origin of the plant, as well as the chemical composition of the nectar and secretions, and is subject to contaminants of diverse nature, namely environmental pollutants, agricultural pesticides, products used in beekeeping besides pathogenic microorganisms that can be incorporated into it during processing [4]. Several authors such as Conti and Botrè [5] and Perugini et al. [6] identify bees and their products as bio-indicators of environmental pollution.

Pollutants, in particular, heavy metals, may be deposited directly on bees, or contaminate them indirectly through nectar, pollen or from ingested water [6,7]. As such, the presence of heavy metals in honey may be indicative of environmental pollution. The control of residues and any adulterants or contaminants in honey provides a sanitary guarantee to this product, which along with the application of good hygiene practices throughout the production chain ensure the provision of a safe

\footnotetext{
* Corresponding author.

E-mail address: hrpezza@iq.unesp.br (H.R. Pezza).
}

and quality product to consumers [8]. Some metal contaminants can be introduced through artificial feeding of the bees. Nutritional supplementation solutions may present high concentrations of $\mathrm{Cd}, \mathrm{Co}, \mathrm{Fe}, \mathrm{K}$, $\mathrm{Mg}, \mathrm{Mn}, \mathrm{Pb}$ and $\mathrm{Na}$, giving rise to contamination during processing [9]. In this work, lead was chosen by reason of its detrimental effects on human health which include fatigue, irritability, anemia, dizziness, headache, sensory disorders, memory loss, muscle tremors and reduced neurophysiological functions [10].

The detection and determination of trace elements in honey essentially require the application of appropriate analytical methodologies. This determination of inorganic constituents in honey is, clearly, not a trivial task given the high level of carbohydrates present in this complex matrix and the low concentration of these analytes. Several techniques have been developed and improved for a better investigation of these compounds in honey and in food products in general. Some of these techniques that merit mentioning include: anodic redissolution voltammetry [11,12]; high resolution inductively coupled plasma mass spectrometry [13]; electrothermal evaporation coupled to inductively coupled plasma mass spectrometry [14]; electrothermal atomic absorption spectrometry [15]; inductively coupled plasma optical emission spectrometry [16]; atomic absorption spectroscopy [5]; atomic absorption spectrometry with graphite furnace [17]; and X-ray fluorescence spectrometry by total reflection [18].

Concentrations of different heavy metals in honey produced in different locations and in different flowering have already been determined in some countries, such as Croatia [1], Poland [19], Turkey [20], Italy [21], Slovenia [22] and Brazil [23]. Spectrophotometric techniques are the most widely employed when it comes to the detection and quantification of heavy metals, with atomic absorption spectrometry being the most widely applied. 
For the intended purposes of our investigation, we proposed the application of a colorimetric assay technique for the determination of $\mathrm{Pb}^{2+}$ in aqueous solution based on the aggregation of the AgNPs in contact with this metal. In other words, AgNPs were induced to aggregate in the presence of $\mathrm{Pb}^{2+}$ through electrostatic interactions and metalnanoparticles. Besides that, a sensitive, fast and robust method that makes use of silver nanoparticles, free of stabilizers, was developed and optimized for lead detection in honey samples of different flowering.

\section{Experimental}

\subsection{Equipment and Materials}

Absorbance measurements were performed using a spectrophotometer (Model HP 8453, Hewlett Packard) equipped with a quartz cuvette $(b=1 \mathrm{~cm}$ ). An analytical balance (AG 204, Mettler Toledo) was used for weighing. A muffle EDG Equipment (Edgcon 3P) and a hot plate were used to promote the mineralization of honey samples. Eppendorfs and micropipettes of 100 to $1000 \mu \mathrm{L}$ were also used for the volumes measured in the experiments.

\subsection{Reagents and Solutions}

All reagents were of analytical grade. The glassware was maintained in $10 \%(\mathrm{v} / \mathrm{v}) \mathrm{HNO}_{3}$ solution for $24 \mathrm{~h}$ and rinsed with deionized water before use. The solutions were prepared with ultrapure water (18 $\mathrm{M} \Omega \mathrm{cm}^{-1}$, Milli-Q system, Millipore). The working solutions were prepared by appropriate dilutions of certified lead stock solution (Sigma Aldrich, 99\%) and at the concentration of $1000 \mathrm{mg} \mathrm{L}^{-1}$. An intermediate working solution of $10 \mathrm{mg} \mathrm{L}^{-1}$ concentration was also prepared by dilution and by the working standards in the range of $0.3-$ $1.0 \mathrm{mg} \mathrm{L}^{-1}$. Nitric acid $(65 \%, \mathrm{v} / \mathrm{v})$ was also used for the mineralization process of honey samples. Working solutions of sodium chloride (Merck, Darmstadt, Germany) were obtained by dilution.

The working solutions of $\mathrm{AgNO}_{3}\left(1.00 \times 10^{-3} \mathrm{~mol} \mathrm{~L}-1,3 \mathrm{~mL}\right)$ and $\mathrm{NaBH}_{4}\left(2.00 \times 10^{-3} \mathrm{~mol} \mathrm{~L}^{-1}, 6 \mathrm{~mL}\right)$ for the synthesis of silver nanoparticles were prepared by diluting their respective stock solutions at the concentration of $1.00 \times 10^{-1} \mathrm{~mol} \mathrm{~L}^{-1}$.

\subsection{Preparation of Silver Nanoparticles}

Silver nanoparticles (AgNPs) were synthesized by chemical reduction of silver nitrate using sodium borohydride as a reducing agent in aqueous solution in the absence of organic stabilizers prepared via the method described by Solomon et al. [24], upon some modifications. The sodium borohydride solution was added to a beaker under constant and vigorous stirring and the silver nitrate solution was then slowly and steadily dripped into the borohydride solution until it exhibited a golden yellow color. Five tests were performed with the aim of obtaining the most stable nanoparticle which is at the same time sensitive to the analyte (lead). Table 1 indicates the volumes and the molar ratio used in the synthesis of each nanoparticle.

After the synthesis, the obtained nanoparticles were stored in a refrigerator at $4 \pm 2.0^{\circ} \mathrm{C}$ and their stability was evaluated for twenty

Table 1

Volumes of $\mathrm{AgNO}_{3}$ and $\mathrm{NaBH}_{4}$ tested for the synthesis of silver nanoparticles and their respective molar ratios.

\begin{tabular}{llll}
\hline Test & $\mathrm{AgNO}_{3}$ volume $(\mathrm{mL})$ & $\mathrm{NaBH}_{4}$ volume $(\mathrm{mL})$ & $\mathrm{AgNO}_{3} / \mathrm{NaBH}_{4}$ molar ratio \\
\hline 1 & 2.0 & 12.0 & $1: 3.00$ \\
2 & 3.0 & 12.0 & $1: 2.00$ \\
3 & 3.5 & 12.0 & $1: 1.71$ \\
4 & 4.0 & 12.0 & $1: 1.50$ \\
5 & 6.0 & 12.0 & $1: 1.00$ \\
\hline
\end{tabular}

four days, a period regarded sufficiently conducive for the development of all experiments required for the research.

\subsection{AgNPs Surface Properties: Possibility of Aggregation Through the Influ-} ence of Ionic Strength and $\mathrm{pH}$

Borohydride is found to play a crucial role in the stabilization of silver nanoparticles. This reducing agent when present in large excessive amount increases the total ionic strength of the system besides promoting the aggregation of the nanoparticles [24]. In view of that, the amount of borohydride should be sufficient to enable the stabilization of the nanoparticles without causing the aggregation of the colloidal solution. Nonetheless, aggregation is also likely to be triggered through the addition of electrolytes, such as $\mathrm{NaCl}$ [25], which may be present in the complex matrix to be evaluated. Bearing these factors into account, the ionic strength was tested using five different concentrations of $\mathrm{NaCl}$, in mol L ${ }^{-1}$ of $1.00 ; 0.50 ; 0.10 ; 0.05 ; 0.01$, aiming at verifying the behavior of the colloidal solution with regard to this electrolyte.

The $\mathrm{pH}$, considered a relevant factor, was likewise tested so as to verify the interference in an eventual possibility of aggregation of the silver nanoparticles obtained. The $\mathrm{pH}$ was changed from 9.0 to 2.5 using $0.50 \mathrm{~mol} \mathrm{~L}^{-1}$ of $\mathrm{HNO}_{3}$. The electrode was calibrated with $\mathrm{pH}$ values of $4.01 \pm 0.02$ and $7.01 \pm 0.02$, prior to each measurement.

\subsection{Analytical Curve}

Upon the optimization of the working nanoparticle, the analytical curve was constructed by adding $200 \mu \mathrm{L}$ aliquot of the AgNPs to 200 $\mu \mathrm{L}$ of standard lead solutions in different concentrations, followed by $800 \mu \mathrm{L}$ of deionized water in quintuplet giving rise to the final concentrations of $0.167 ; 0.150 ; 0.133 ; 0.117 ; 0.100 ; 0.0830 ; 0.0670$; $0.0500 \mathrm{mg} \mathrm{L}^{-1}$, respectively. The assays were performed aiming at reading the respective analytical signals, the absorbances, by means of a spectrophotometer at the wavelength of $393 \mathrm{~nm}$.

\subsection{Samples of Honey}

Six samples of honey, from three different flowering plants (eucalyptus, orange and grapevine), were purchased directly from a beekeeper in the city of Araraquara/SP and were used to evaluate the performance of the proposed method.

\subsection{Dry Digestion Procedure of the Samples}

Based on the method proposed by Conti and Botrè [5], with some modifications, ten grams of each sample of honey were placed in a porcelain crucible for reduction to ashes in muffle using a temperature gradient of the oven at $30^{\circ} \mathrm{C}$ until reaching the final temperature of $550 \pm 5$ ${ }^{\circ} \mathrm{C}$. The samples were mineralized for $6 \mathrm{~h}$ in order to guarantee the total destruction of all organic matter, until obtaining ash residues in white and/or gray. After $6 \mathrm{~h}$, the residue was cooled to room temperature and dissolved in $2 \mathrm{~mL}$ of $\mathrm{HNO}_{3}(65 \%, \mathrm{v} / \mathrm{v})$. The solution was taken to a heating plate for the slow evaporation of nitric acid to ensure the presence of only inorganic residues in the final product. The solution was finally transferred to a $10 \mathrm{~mL}$ volumetric flask and quenched with deionized water. A solution of $0.1 \mathrm{~mol} \mathrm{~L}^{-1}$ of $\mathrm{NaOH}$ was used in order to operate under the same $\mathrm{pH}$ range of the standard lead solutions in contact with silver nanoparticles.

\subsection{Study of Interferences}

The interferences were evaluated by studying the behavior of the reaction in the presence of some metals commonly found in honey including cadmium, copper, cobalt, chromium, iron, aluminum and nickel. The concentrations, being 10 times greater than that of lead metal, were assessed under the same conditions described for the samples. 


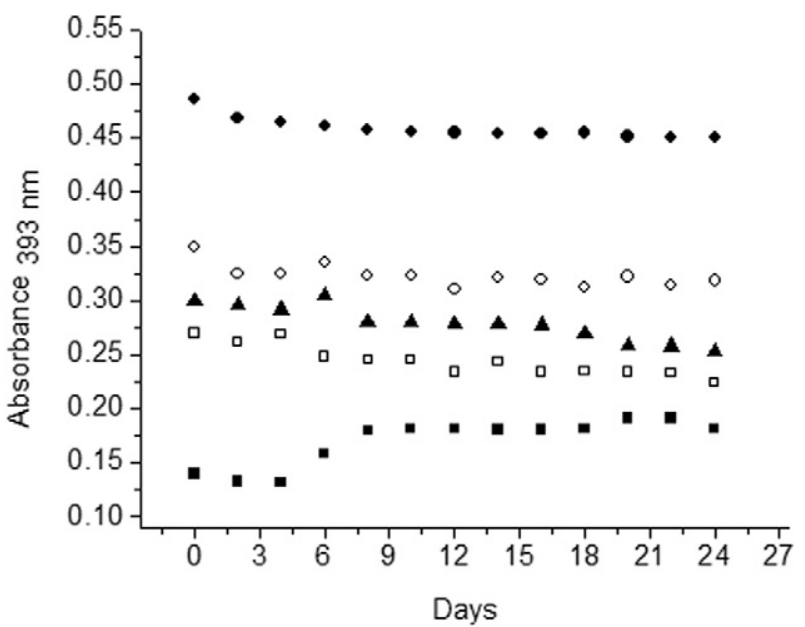

Fig. 1. Stability of the nanoparticles $1(\boldsymbol{\square}), 2(\square), 3(\boldsymbol{\Delta}), 4(\bigcirc)$ and $5(\bullet)$ synthesized with different molar ratios of the precursor solutions of $\mathrm{AgNO}_{3}$ and $\mathrm{NaBH}_{4}$.

After having defined some of the probable interfering ions, a study aimed at confirming the interference hypothesis was performed using the interference factor (I.F.) for each ion. The interference factor is calculated by the mathematical ratio of the absorption of the lead ion (II) to the interfering ion $(\triangle \mathrm{Abs}(\mathrm{Pb}(\mathrm{II})+$ interfering ion $))$ through the variation of absorbance of the lead ion (II) $(\triangle \mathrm{Abs}(\mathrm{Pb}(\mathrm{II}))$ ). Interference factors below 0.95 and greater than 1.05 are associated with interference effect [26]. As a result of the treatment process of honey samples (high temperature and use of nitric acid), all proteins present in the medium are denatured with the total loss of activity [27], hence, there is no need to perform an interference test on proteins.

\subsection{Matrix Effect Study: Pattern Addition and Recovery}

The proposed method was validated through standard addition and by investigating the possible effects associated with the matrix under study - honey. The samples were fortified with lead solution at 50 , $100,150 \%$ of the maximum concentration allowed by the legislation [28]. They were then analyzed via the proposed and comparative methods. All analyses were performed in five-fold.

\subsection{Comparative Method}

Flame atomic absorption spectrometry (FAAS) presents a relatively low cost and has excellent analytical performances. It is probably the most widely applied technique for the analysis of a variety of metals in foods. The conventional way to perform such determinations involves a mineralization phase in order to obtain a suitable solution to be introduced into the spectrometer.
Honey samples were analyzed by FAAS as a comparative method [29-31] aiming at confirming the robustness and reliability of the proposed method. A FAAS Varian SpectrAA 50 spectrometer was used in the experiments for lead determination in honey samples. For the measurements, some operational parameters were set including wavelength at $217 \mathrm{~nm}$, slot width of $1 \mathrm{~nm}$ and operation carried out under air-acetylene flame.

\section{Results and Discussion}

Preliminary tests with silver nanoparticles synthesized with different volumes of $\mathrm{AgNO}_{3}$ and $\mathrm{NaBH}_{4}$ were performed with the objective of obtaining a stable nanoparticle and improving the sensitivity of the proposed method for lead determination in honey samples.

Following the synthesis of the AgNPs, a stability test was performed. As can be observed in Fig. 1, the nanoparticle number 5 exhibited the highest absorbance and the best stability among all the nanoparticles during the period under analysis.

Based on the stability test, the nanoparticle number 5 was chosen as the working AgNP owing to the fact that it presented the highest stability and the greatest absorbance compared to the other nanoparticles tested. All nanoparticles were synthesized in the absence of stabilizing agents. Bittar et al. [32] concluded that stabilizing agents actually prevent the analyte of interest from reacting with silver nanoparticles, since these stabilizing agents form a coating around the nanoparticles, rendering the nanoparticle-analyte interaction difficult. Fig. 2 shows the absorbance spectrum of AgNP at $393 \mathrm{~nm}$, which is symmetrical and narrow in shape and the transmission electron microscopy images of the silver nanoparticles. These features ensure the presence of monodisperse nanoparticles.

\subsection{Interference of Ionic Strength and $\mathrm{pH}$ in the Aggregation of AgNPs}

A study of the interference of the electrolyte present in the colloidal medium of the nanoparticles was performed. Fig. 3 depicts the absorbance obtained for the working nanoparticle in the presence of different concentrations of the $\mathrm{NaCl}$ electrolyte.

Based on the data obtained, we observed that the stabilization of the AgNPs is less efficient in the presence of high concentrations of the electrolyte. This can be explained by the fact that in the presence of high salt concentration, the sodium borohydride ceases to be a good stabilizing agent, thereby providing a weak steric stabilization of the silver ions [25]. It is possible to consider that in concentrations of $\mathrm{NaCl}$ equal to $0.10 ; 0.05$ and $0.01 \mathrm{~mol} \mathrm{~L}^{-1}$, the nanoparticles are stable, since the addition of concentrations equal to or greater than $0.50 \mathrm{~mol} \mathrm{~L}^{-1}$ causes the destruction of the colloidal solution of nanoparticles and their consequent aggregation as a result of the increase in the ionic strength of the medium.

The $\mathrm{pH}$ was evaluated starting from the original AgNP solution, which after synthesis presented $\mathrm{pH}$ equal to 9.2. As the pretreatment
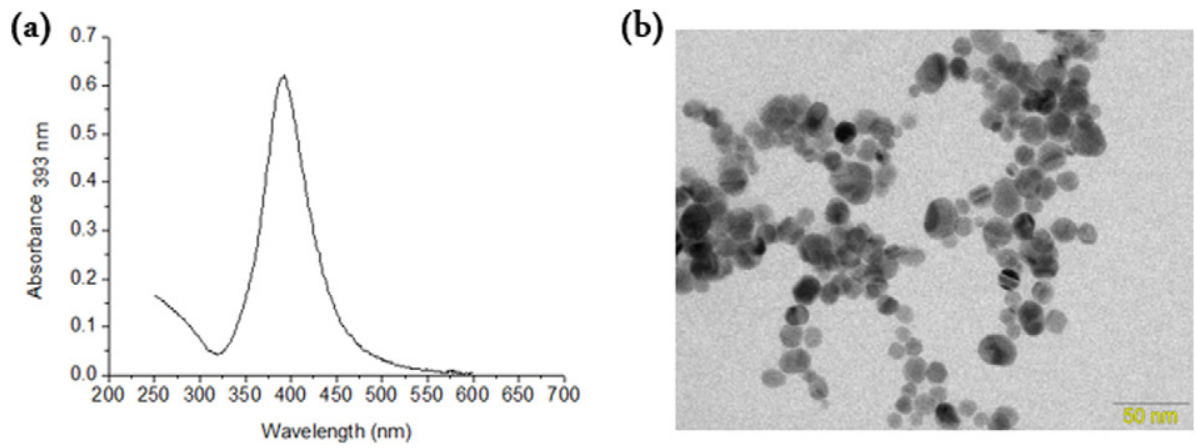

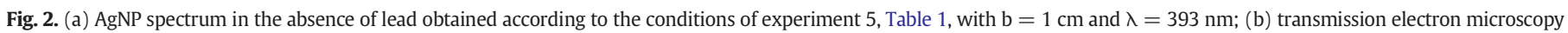
images of the silver nanoparticles. 


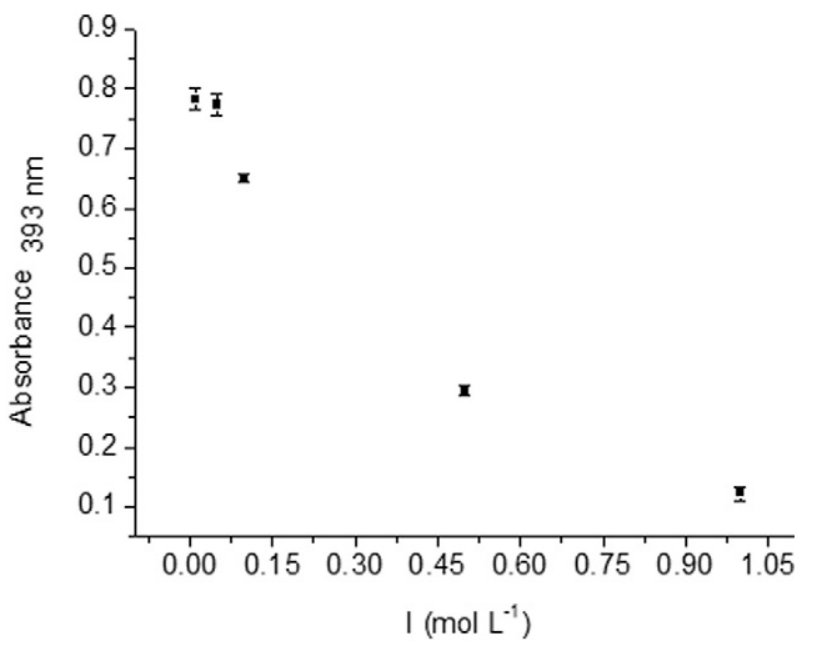

Fig. 3. Absorbance behavior of the working AgNP obtained in the presence of the different concentrations of $\mathrm{NaCl}: 1.00,0.50,0.10,0.05$, and $0.01 \mathrm{~mol} \mathrm{~L}^{-1}$, respectively.

of the honey samples investigated entailed the addition of concentrated $\mathrm{HNO}_{3}$ in the mineralization process, an assessment was made relative to the importance of testing the influence of $\mathrm{pH}$ on the stability of AgNPs. Fig. 4 shows the relationship between absorbance and $\mathrm{pH}$ of the working nanoparticle. The $\mathrm{pH}$ was reduced with the aid of a solution of $\mathrm{HNO}_{3}$ $0.1 \mathrm{~mol} \mathrm{~L}^{-1}$.

Based on what was observed, we arrived at the conclusion that following the mineralization of the honey samples there was a need to correct the final solution $\mathrm{pH}$ to $\mathrm{pH} 4.2$, restoring the $\mathrm{pH}$ of the system. Thus, the aggregation of the nanoparticles would be avoided when they are in contact with the samples to be analyzed. To this end, $0.1 \mathrm{~mol} \mathrm{~L}^{-1}$ of $\mathrm{NaOH}$ solution was employed and this led to coherent and reliable results.

\subsection{Analytical Figures of Merit}

The merit figures of the analytical method included the limits of detection (LOD) and quantification (LOQ), precision, accuracy, and linear range. Under optimized experimental conditions, a linear response was obtained for the final lead concentrations between 0.0500 and $0.167 \mathrm{mg} \mathrm{L}^{-1}$. Repeatability tests using intra-day measurements of standard solutions of $0.050 \mathrm{mg} \mathrm{L}^{-1}$ and $0.100 \mathrm{mg} \mathrm{L}^{-1}$ resulted in relative standard deviations (\% RSD) of 1.2 and $4.2 \%$ while tests using inter-day measurements of the same solutions resulted in relative

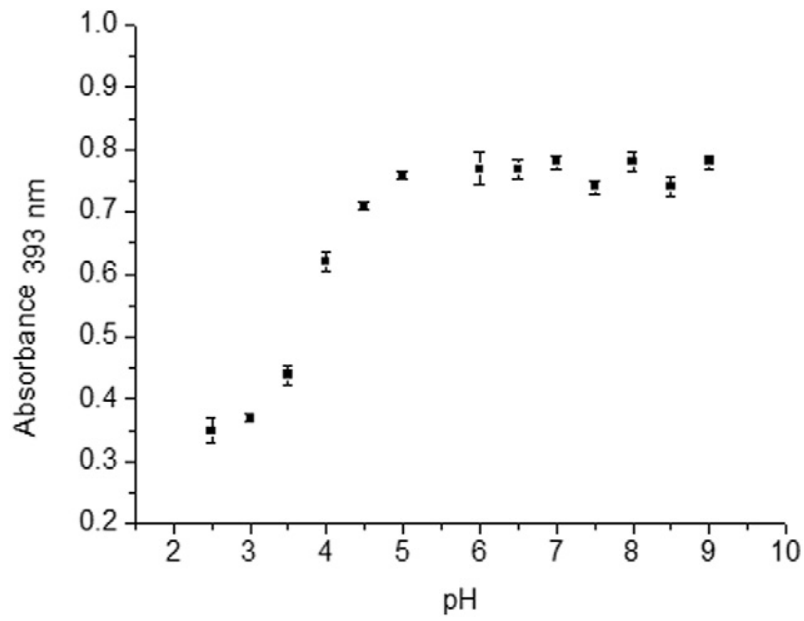

Fig. 4. Relationship between absorbance and $\mathrm{pH}$ of silver nanoparticles colloidal solution $(\lambda=393 \mathrm{~nm})$.
Table 2

Analytical characteristics of the proposed method for lead analysis.

\begin{tabular}{ll}
\hline Parameters & Values \\
\hline Linear Range & $0.0500-0.167 \mathrm{mg} \mathrm{L}^{-1}$ \\
Correlation coefficient(R) & 0.994 \\
Equation & $\mathrm{A}=0.702-3.646 \times \mathrm{C}_{\mathrm{Pb}}$ \\
LOD $\left(\mathrm{mg} \mathrm{L}^{-1}\right)$ & 0.0135 \\
LOQ $\left(\mathrm{mg} \mathrm{L}^{-1}\right)$ & 0.0451 \\
Wavelength $(\mathrm{nm})$ & 393 \\
\hline
\end{tabular}

standard deviations (\% RSD) of 2.6 and $1.0 \%$, respectively. The analytical curve and its parameters are presented in Table 2.

LOD and LOQ were determined according to IUPAC recommendations [33] using the expressions $3 \times(s / b)$ and $10 \times(s / b)$, respectively, where $s$ is the standard deviation of the points of the curve while $b$ stands for the slope of the linear range. The calculated LOD and LOQ values were 0.0135 and $0.0451 \mathrm{mg} \mathrm{L}^{-1}$, respectively. Fig. 5 shows the analytical curve and the different colorations, in other words, the screening obtained by the system among the silver nanoparticles in the presence of different lead concentrations.

As the studies evolved, new maximum limits were established for contaminants in honey, as established by the normative instruction n-8 of 2010, of the Ministry of Livestock and Supply [34]. This normative instruction approved the programs for the control of residues and contaminants in meat (bovine, poultry, pork and equine), milk, honey, eggs and fish for fiscal year 2010. In the case of honey, the maximum level of $0.50 \mathrm{mg} \mathrm{kg}^{-1}$ was allowed for $\mathrm{As}, \mathrm{Cd}, \mathrm{Pb}$ and $\mathrm{Hg}$.

In 2011, MERCOSUL established a maximum lead limit of $0.30 \mathrm{mg} \mathrm{kg}^{-1}$ in honey samples. This limit was adopted by Brazil once the country is a member of MERCOSUL. For the development of this work and by virtue of the fact that they present relatively better sensitivity, silver nanoparticles were used for further tests in order to detect the presence or absence of lead contaminant in the analyzed samples.

\subsection{Study of Interferences}

The study of potential interfering metals was performed considering the typical composition of the honey samples, with evaluation of the

(a)

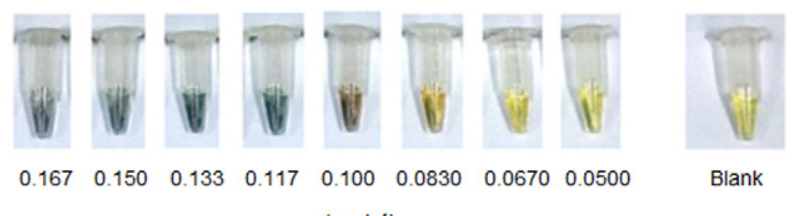

(b)

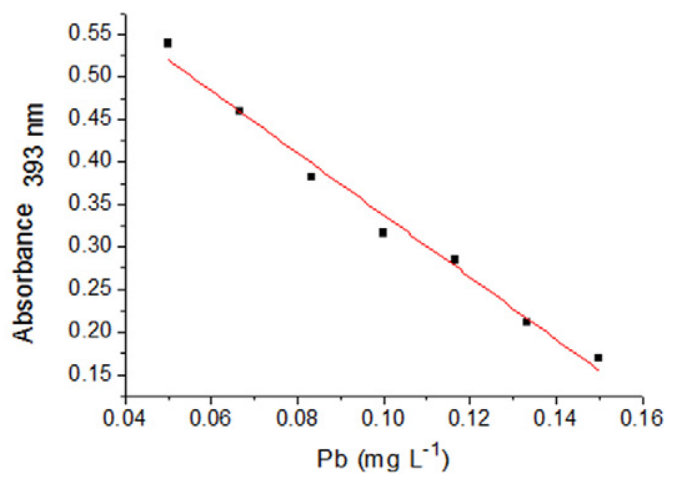

Fig. 5. (a) Colors obtained for different concentrations of lead in the presence of AgNPs and a blank in the absence of the analyte; (b) Calibration curve obtained by the measured absorbance $(\lambda=393 \mathrm{~nm})$ of the AgNPs system with final lead concentrations of 0.0500 ; $0.0670 ; 0.0830 ; 0.100 ; 0.117 ; 0.133 ; 0.150 ; 0.167 \mathrm{mg} \mathrm{L}^{-1}$, respectively. 
Table 3

Interference factors of some metals commonly found in honey.

\begin{tabular}{ll}
\hline Metals & Interference factor (I.F.) \\
\hline $\mathrm{Cd}$ & 0.957 \\
$\mathrm{Cu}$ & 0.962 \\
$\mathrm{Co}$ & 0.972 \\
$\mathrm{Cr}$ & 0.998 \\
$\mathrm{Fe}$ & 0.978 \\
$\mathrm{Al}$ & 0.968 \\
$\mathrm{Ni}$ & 1.003 \\
\hline
\end{tabular}

effects of seven metals commonly found in this type of matrix. Table 3 was constructed based on the values obtained. As can be noted, no interferences were observed in the proposed method for the interfering concentrations tested.

By observing the values of the interference factors calculated and presented in Table 3 for each ion, one will notice that all of them presented values within the range of 0.95 to 1.05 , in other words, with percentages below the tolerable limit (5.0\%). Thus, it is possible to observe a negative interference effect, i.e., all the ions tested are not interfering agents.

\subsection{Addition and Recovery Tests: Application in Honey Samples of Different Flowering}

Preliminary tests for lead quantification in honey samples were performed. It is noteworthy that none of the methods (both proposed and comparative) indicated the presence of heavy metals. As a result, we evaluated the need to perform standard addition tests on the analyzed samples.

The accuracy of the proposed method was assessed by fortification tests performed on the complex honey matrix of three different flowering plants (a eucalyptus flora, an orange flora and a grapevine flora). Table 4 shows the data obtained for the fortification tests $\left(0.30 \mathrm{mg} \mathrm{kg}^{-1}\right)$. The concentration of $\mathrm{Pb}$ was determined by the use of standard solutions of $\mathrm{Pb}$ at concentrations 50,100 and $150 \%$ superior to the maximum concentration in honey $\left(0.30 \mathrm{mg} \mathrm{kg}^{-1}\right)$ allowed by law. The mean values were obtained from five replicates performed for each type of honey.

The results obtained by $t$-test, for the average comparison of the repetitions of the proposed and comparative methods proved that there were no significant differences between them (with a confidence level of $95.0 \%$ ). This demonstrated that the results obtained by the two methods were comparable. For the purpose of confirming this outcome, the data obtained were statistically analyzed. Table 4 also shows that the application of the paired Student's $t$-test was indispensable, as the calculated $t$-value was less than the tabulated $t$-value. These results reinforce the fact that there was no significant difference between the two methods.

The use of AgNPs for lead detection in complex honey matrix has not yet been described in the literature. Several other methods have already been used for the detection of lead as well as other trace metals in honey samples at extremely low concentrations. For instance, for Italian honeys, the concentration of lead found was between 3.2 and $186 \mathrm{ng} \mathrm{g}^{-1}[11,13,14,35]$. Uren et al. [36] reported to have obtained concentrations between 32.9 and $55.2 \mathrm{ng} \mathrm{g}^{-1}$ for Turkish samples. Celechovska 'and Vorlova' [37] have also previously found values close to $1000 \mathrm{ng} \mathrm{g}^{-1}$ in Czech honey samples.

In a study by Vanhanen et al. [38], the average levels of heavy metals in New Zealand honey were $1.180,0.149$ and $0.017 \mathrm{mg} \mathrm{kg}^{-1}$ for Zn, Cd and $\mathrm{Pb}$, respectively. These values could be compared to the quantities of heavy metals reported in honey samples from Poland, which were $0.048,0.015$ and $7.76 \mathrm{mg} \mathrm{kg}^{-1}$ of $\mathrm{Zn}, \mathrm{Cd}$ and $\mathrm{Pb}$, respectively [19]. Based on the data reported for New Zealand honey, it is worth noting that lead metal was not detected in five of the ten types of honey analyzed in the country while the average of this metal found in honey samples from the country was 450 times lower compared to those from Poland [19].

Thus, the results presented in our present work are, in essence, coherent and reliable. They point to the absence of lead metal in the samples analyzed. Furthermore, acceptable values were obtained for the recovery tests conducted. Clearly, the proposed screening method using silver nanoparticles devoid of stabilizers is, indeed, a method that has great potential for application in honey samples.

The proposed method has demonstrated to be an essentially efficient alternative and clearly more advantageous compared to most of the previously reported methods for the analysis of lead in honey. The fact that it is fast, easy to conduct, and allows viewing the detection signal through the naked eyes makes this method analytically worthy of appreciation. While the method exhibited lower sensitivity compared to the other methods described in the literature, it is sufficiently sensitive for the determination of lead in honey in amounts lower than those established by law.

Table 4

Recovery values obtained using the proposed method (AgNP) and the comparative method (FAAS) as well as the values of calculated-t (Student's $t$-test) for the two methods.

\begin{tabular}{|c|c|c|c|c|c|c|}
\hline Samples & $\begin{array}{l}\text { Added value } \\
\left(\mathrm{mg} \mathrm{kg}^{-1}\right)\end{array}$ & $\begin{array}{l}\text { Value found (mg kg } \\
\text { (Proposed method) }\end{array}$ & Recovery (\%) & $\begin{array}{l}\text { Value found ( } \mathrm{mg} \mathrm{kg}^{-1} \text { ) } \\
\text { (Comparative method) }\end{array}$ & Recovery (\%) & Student's $t$-test: calculated-t value ${ }^{*}$ \\
\hline \multirow[t]{3}{*}{ Eucalyptus honey $^{\mathrm{a}}$} & 0.45 & $0.504 \pm 0.05$ & $112.02 \pm 11.84$ & $0.365 \pm 0.03$ & $81.21 \pm 7.25$ & \\
\hline & 0.60 & $0.565 \pm 0.09$ & $94.10 \pm 15.52$ & $0.639 \pm 0.10$ & $106.57 \pm 16.31$ & 0.967 \\
\hline & 0.75 & $0.798 \pm 0.05$ & $106.37 \pm 6.80$ & $0.651 \pm 0.03$ & $86.84 \pm 4.35$ & \\
\hline \multirow[t]{3}{*}{ Orange honey $^{\mathrm{a}}$} & 0.45 & $0.591 \pm 0.07$ & $119.04 \pm 14.40$ & $0.497 \pm 0.12$ & $110.33 \pm 27.12$ & \\
\hline & 0.60 & $0.689 \pm 0.07$ & $114.89 \pm 11.74$ & $0.663 \pm 0.03$ & $110.54 \pm 5.44$ & 1.552 \\
\hline & 0.75 & $0.776 \pm 0.08$ & $103.40 \pm 10.80$ & $0.770 \pm 0.03$ & $102.73 \pm 4.35$ & \\
\hline \multirow[t]{3}{*}{ Grape fruit honey $^{\mathrm{a}}$} & 0.45 & $0.586 \pm 0.04$ & $120.36 \pm 9.79$ & $0.425 \pm 0.03$ & $94.44 \pm 7.25$ & \\
\hline & 0.60 & $0.607 \pm 0.08$ & $101.13 \pm 13.24$ & $0.544 \pm 0.03$ & $90.69 \pm 5.44$ & 1.968 \\
\hline & 0.75 & $0.779 \pm 0.04$ & $103.94 \pm 5.86$ & $0.759 \pm 0.07$ & $101.14 \pm 8.70$ & \\
\hline \multirow[t]{3}{*}{ Eucalyptus honey $^{\mathrm{b}}$} & 0.45 & $0.510 \pm 0.06$ & $113.33 \pm 14.26$ & $0.377 \pm 0.03$ & $83.86 \pm 5.92$ & \\
\hline & 0.60 & $0.582 \pm 0.06$ & $97.06 \pm 10.69$ & $0.532 \pm 0.04$ & $88.70 \pm 5.44$ & 3.919 \\
\hline & 0.75 & $0.774 \pm 0.11$ & $103.13 \pm 14.66$ & $0.675 \pm 0.03$ & $90.02 \pm 3.55$ & \\
\hline \multirow[t]{3}{*}{ Orange honey ${ }^{\mathrm{b}}$} & 0.45 & $0.384 \pm 0.04$ & $85.34 \pm 9.14$ & $0.354 \pm 0.03$ & $78.56 \pm 7.25$ & \\
\hline & 0.60 & $0.560 \pm 0.05$ & $93.40 \pm 7.61$ & $0.473 \pm 0.03$ & $78.77 \pm 5.44$ & 3.626 \\
\hline & 0.75 & $0.701 \pm 0.06$ & $93.52 \pm 5.98$ & $0.616 \pm 0.03$ & $82.08 \pm 3.55$ & \\
\hline \multirow[t]{3}{*}{ Grapefruit honey $^{\mathrm{b}}$} & 0.45 & $0.505 \pm 0.05$ & $112.26 \pm 11.72$ & $0.342 \pm 0.03$ & $75.91 \pm 5.92$ & \\
\hline & 0.60 & $0.540 \pm 0.06$ & $90.02 \pm 9.91$ & $0.461 \pm 0.03$ & $76.79 \pm 4.44$ & 3.742 \\
\hline & 0.75 & $0.681 \pm 0.06$ & $90.74 \pm 7.60$ & $0.604 \pm 0.03$ & $80.49 \pm 4.35$ & \\
\hline
\end{tabular}

\footnotetext{
a Honey collected in the second half of 2015

b Honey collected in the first half of 2016.

* Student's $t$-test: tabulated $t$-value $=4.3027$ (95\% confidence level).
} 


\section{Conclusion}

In this work, the proposed methodology for lead determination using stabilizer-free silver nanoparticles has proven to be suitably effective and reliable. With the aid of calibration curve, we were able to obtain an LOQ of around $0.0451 \mathrm{mg} \mathrm{L}^{-1}$ (or $0.0451 \mathrm{mg} \mathrm{kg}^{-1}$ ) which is relatively lower compared to the value allowed by the current legislation. Remarkably, the mineralization of the honey samples for subsequent tests was found to be effective while the interferences of the matrix through the fortification process of the samples were carried out without the need of the presence of organic compounds in the medium. The results obtained clearly demonstrate the method potential for application in the quantification of $\mathrm{Pb}$ in honey samples of different flowering.

\section{Acknowledgements}

The authors would like to express their sincerest gratitude and indebtedness to the Brazilian research funding agencies - CAPES and $\mathrm{CNPq}$, for the financial support provided during the course of this research.

\section{References}

[1] N. Bilandzić, M. Dokić, M. Sedak, B.S. Kolanović, I. Varenina, A. Koncurat, N. Rudan, Determination of trace elements in Croatian floral honey originating from different regions, Food Chem. 128 (2011) 1160-1164.

[2] B. Fallico, M. Zappala, E. Arena, A. Verzera, Effects of conditioning on HMF content in unifloral honeys, Food Chem. 85 (2004) 305-313.

[3] M. Kuçüc, S. Kolaylı, S. Karaoglu, E. Ulusoy, C. Baltacı, F. Candan, Biological activities and chemical composition of three honeys of different types from Anatolia, Food Chem. 100 (2007) 526-534.

[4] M.R. Martinho, A criação de abelhas, Publicações Globo Rural, Rio de Janeiro, 1988.

[5] M.E. Conti, F. Botrè, Honeybees and their products as potential bioindicators of heavy metals contamination, Environ. Monit. Assess. 69 (2000) 267-282.

[6] M. Perugini, M. Manera, L. Grotta, M.C. Abete, R. Tarasco, M. Amorena, Heavy metal $(\mathrm{Hg}, \mathrm{Cr}, \mathrm{Cd}$ and $\mathrm{Pb})$ contamination in urban areas and wildlife reserves: honeybees as bioindicators, Biol. Trace Elem. Res. 140 (2011) 170-176.

[7] C. Porrini, A.G. Sabatini, S. Girotti, S. Ghini, P. Medrzycki, F. Grillenzoni, L. Bortolotti, E. Gattavecchia, G. Celli, Honey bees and bee products as monitors of the environmental contamination, Apiacta 38 (2003) 63-70.

[8] PAN, 2011-2013, Programa Apícola Nacional Triénio de 2011-2013, Ministério da Agricultura, do desenvolvimento rural e das pescas, 2010.

[9] P. Pohl, Determination of metal content in honey by atomic absorption and emission spectrometries, Trends Anal. Chem. 28 (2009) 117-128.

[10] O.A. Davies, M.E. Allison, H.S. Uyi, Bioaccumulation of heavy metals in water, sediment and periwinkle (Tympanotonusfuscatusvar radula) from the Elechi Creek, Niger Delta, Afr. J. Biotechnol. 5 (2006) 968-973.

[11] G. Sanna, M.I. Pilo, P.C. Piu, A. Tapparo, R. Seeber, Determination of heavy metals in honey by anodic stripping voltammetry at microelectrodes, Anal. Chim. Acta 415 (2000) 165-173.

[12] A. Hassan, M.A.A. Ghandour, A.M.M. Ali, H.A. Mahran, Evaluation of lead, cadmium and copper concentrations in bee honey and edible molasses, Am. J. Appl. Sci. 7 (2010) 315-322.

[13] S. Caroli, G. Forte, A.L. Iamiceli, B. Galoppi, Determination of essential and potentially toxic trace elements in honey by inductively coupled plasma-based techniques, Talanta 50 (1999) 327-336.

[14] M. Bettinelli, U. Baroni, S. Spezia, C. Terni, Determination of trace elements in honey using ETV-ICP-MS, At. Spectrosc. 21 (2000) 195-204.

[15] J.C.R. García, J. Barciela García, C. Herrero Latorre, S. García Martín, R.M. Peña Crecente, Comparison of palladium-magnesium nitrate and ammonium dihydrogen phosphate modifiers for lead determination in honey by electrothermal atomic absorption spectrometry, Food Chem. 91 (2005) 435-442.

[16] Z. Leblebici, A. Aksoy, Determination of heavy metals in honey samples from central Anatolia using plasma optical emission Spectrofotometry (ICP-OES), Pol. J. Environ. Stud. 17 (2008) 549-555.

[17] Z. Ajtony, L. Bencs, R. Haraszi, J. Szigeti, N. Szoboszlai, Study on the simultaneous determination of some essential and toxic trace elements in honey by multi-element graphite furnace atomic absorption spectrometry, Talanta 71 (2007) 683-690.

[18] P. Kump, M. Necemer, J. Snajder, Determination of trace elements in bee honey, pollen and tissue by total reflection and radioisotope X-ray fluorescence spectrometry, Spectrochim. Acta B 51 (1996) 499-507.

[19] P. Przybylowski, A. Wilczynska, Honey as an environmental marker, Food Chem. 74 (2001) 289-291.

[20] S. Silici, O.D. Uluozlu, M. Tuzen, M. Soylak, Assessment of trace element levels in Rhododendron honeys of Black Sea Region, Turkey, J. Hazard. Mater. 156 (2008) 612-618.

[21] A. Pisani, G. Protano, F. Riccobono, Minor and trace elements in different honey types produced in Siena County (Italy), Food Chem. 107 (2008) 1553-1560.

[22] T. Golob, U. Doberšek, P. Kump, M. Necemer, Determination of trace and minor elements in Slovenian honey by total reflection X-ray fluorescence spectroscopy, Food Chem. 91 (2005) 593-600.

[23] R.O.R. Ribeiro, E.T. Mársico, E.F.O. Jesus, C.S. Carneiro, C.A.C. Júnior, E. Almeida, V.F.N. Filho, Determination of trace elements in honey from different regions in Rio de Janeiro State (Brazil) by total reflection X-ray fluorescence, J. Food Sci. 79 (2014) $738-742$.

[24] S.D. Solomon, M. Bahadory, A.V. Jeyarajasingam, S.A. Rutkowsky, C. Boritz, L Mulfinger, Synthesis and study of silver nanoparticles, J. Chem. Educ. 2 (2007) 322-325.

[25] D. Radziuk, A. Skirtach, G. Sukhorukov, D. Shchukin, H. Möhwald, Stabilization of silver nanoparticles by polyelectrolytes and poly(ethylene glycol), Macromol. Rapid Commun. 28 (2007) 848-855.

[26] S.P. Eiras, J.C. Andrade, R.E. Bruns, Catalytic determination of molybdenum-VI in plants using mono-segmented continuous-flow analysis and spectrophotometric detection, Analyst 118 (1993) 213-217.

[27] F. Mallamace, et al., Energy landscape in protein folding and unfolding, PNAS 113 (2016) 3159-3163.

[28] MERCOSUL, Mercado Comum do Sul. GMC/RES nº 012/2011, Regulamento técnico MERCOSUL sobre limites máximos de contaminantes inorgânicos em alimentos, http://www.http://bvsms.saude.gov.br/bvs/saudelegis/anvisa/2013/rdc0042_29_ 08_2013.html 2011, Accessed date: 2 June 2017.

[29] V.A. Lemos, G.T. David, An on-line cloud point extraction system for flame atomic absorption spectrometric determination of trace manganese in food samples, Microchem. J. 94 (2010) 42-47.

[30] D. Citak, M. Tuzen, A novel preconcentration procedure using cloud point extraction for determination of lead, cobalt and copper in water and food samples using flame atomic absorption spectrometry, Food Chem. Toxicol. 48 (2010) 1399-1404.

[31] S.L.C. Ferreira, M.A. Bezerra, W.N.L. dos Santos, B.B. Neto, Application of Doehlert designs for optimization of an on-line preconcentration system for copper determination by flame atomic absorption spectrometry, Talanta 61 (2003) 295-303.

[32] D.B. Bittar, T.A. Catelani, K. Nigoghossian, H.D.S. Barud, S.J.L. Ribeiro, L. Pezza, H.R. Pezza, Optimized synthesis of silver nanoparticles by factorial design with application for the determination of melamine in milk, Anal. Lett. 50 (2017) 829-841.

[33] G.L. Long, J.D. Winefordner, Limit of detection a closer look at the IUPAC definition, Anal. Chem. 55 (1983) 712-724.

[34] BRASIL, Ministério da Agricultura, Pecuária e Abastecimento. Aprova o Programa de Controle de Resíduos e Contaminantes em Carnes (Bovina, Aves, Suína e Equina), Leite, Mel, Ovos e Pescado para o exercício de 2010. Instrução Normativa $n^{\circ} 8$, de 29 de abril de 2010, Diário Oficial da União, Brasília, 3 de maio de 2010.

[35] S. Caroli, G. Forte, M. Alessandrelli, R. Cresti, M. Spagnoli, S. D'Ilio, J. Pauwels, G.N. Kramer, A pilot study of the production of a certified reference material for trace elements in honey, Microchem. J. 67 (2000) 227-233.

[36] A. Uren, A. Serifoglu, Y. Sarikahya, Distribution of elements in honeys and effect of a thermoelectric power plant on the element contents, Food Chem. 61 (1998) 185-190.

[37] O. Celechovská, L. Vorlová, Groups of honey - physicochemical properties and heavy metals, Acta Vet. Brno 70 (2001) 91-95.

[38] L.P. Vanhanen, A. Emmertz, G.P. Savage, Mineral analysis of mono-floral New Zealand honey, Food Chem. 128 (2011) 236-240. 